WellBeing International

WBI Studies Repository

$12-2001$

\title{
The Evolution of Animal Play, Emotions, and Social Morality: On Science, Theology, Spirituality, Personhood, and Love
}

Marc Bekoff

University of Colorado

Follow this and additional works at: https://www.wellbeingintlstudiesrepository.org/acwp_sata

Part of the Animal Studies Commons, Behavior and Ethology Commons, and the Comparative Psychology Commons

\section{Recommended Citation}

Bekoff, M. (2001). The evolution of animal play, emotions, and social morality: on science, theology, spirituality, personhood, and love. Zygon ${ }^{\circ}, 36(4), 615-655$.

This material is brought to you for free and open access by WellBeing International. It has been accepted for inclusion by an authorized administrator of the WBI Studies Repository. For more information, please contact wbisr-info@wellbeingintl.org.

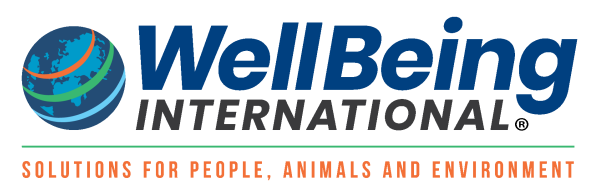




\title{
The Evolution of Animal Play, Emotions, and Social Morality: On Science, Theology, Spirituality, Personhood, and Love
}

\author{
Marc Bekoff \\ University of Colorado
}

\section{$\underline{\text { KEYWORDS }}$}

animal emotions, animal play, biocentric anthropomorphism, critical anthropomorphism, personhood, social morality, spirituality

\section{$\underline{\text { ABSTRACT }}$}

My essay first takes me into the arena in which science, spirituality, and theology meet. I comment on the enterprise of science and how scientists could well benefit from reciprocal interactions with theologians and religious leaders. Next, I discuss the evolution of social morality and the ways in which various aspects of social play behavior relate to the notion of "behaving fairly." The contributions of spiritual and religious perspectives are important in our coming to a fuller understanding of the evolution of morality. I go on to discuss animal emotions, the concept of personhood, and how our special relationships with other animals, especially the companions with whom we share our homes, help us to define our place in nature, our humanness. It is when we take the life of another being in the ritual of compassionately euthanizing them ("putting them to sleep") that who we are in the grand scheme of things comes to the fore. I end with a discussion of the importance of ethological studies, behavioral research in which a serious attempt is made to understand animals in their own worlds, inquiries in which it is asked, "What is it like to be another species?" Species other than nonhuman primates need to be studied. I plead for developing compassionate, heartfelt, and holistic science that allows for interdisciplinary talk about respect, grace, spirituality, religion, love, Earth, and God.

\section{SOME PERSONAL REFLECTIONS: EMBODIMENT, EMERGENCE, AND A SOCIAL PHENOMENON KNOWN AS "MARC"}

Who am I? What am I? Where am I? When am I? Asking these questions is a useful way to begin my discussion of my spiritual quest in which I want to bring together my brand of science-ethology, the study of animal behavior-and my spirituality. It has been a long, at times difficult, and rewarding courtship that each day gets closer to the altar. It is very clear that learning about other animal beingshow they spend their time, who they interact with, where they do what they do and how, their intellectual and cognitive abilities (cognitive ethology), and their deep emotional lives-is essential for gaining a full appreciation of human spirituality and what it is to be human. Tool use, language use, self-awareness and 
self-consciousness, culture, art, and rationality no longer can reliably be used to draw species boundaries that separate human from nonhuman animal beings (hereafter animals; for a discussion of human uniqueness blending theological and cognitive perspectives see Peterson 1999, who concludes that the study of animal minds weakens claims about human uniqueness). Such speciesistic claims that only humans use tools and language, are self-aware, have culture, or reason are no longer defensible given the enormous growth in our knowledge of our animal kin with whom we share this planet. Indeed, as I will discuss here, some animals can justifiably be called "persons," whereas humans do not always fulfill the criteria for the granting of "personhood."

Who am I? What am I? Where am I? When am I? We have all thought deeply about these questions, and at least for me (as far as I can parse who "me" is) the answers seem to change daily or even more often. The various iterations are at once unnerving, intriguing, and amusing, and always mysterious, and only make me want to know more about myself and the world in which I am presently situated. To be sure, the various editions of the answers to the questions "Who am I? What am I? Where am I? and When am I?" drive me deeper and deeper into my own spirituality, into my own humanness, in which tangible and intangible elements reside, resonate, radiate, and freely associate in the existential milieu. No matter what the temporary answers turn out to be, it is always a rich sense of unfettered amazement and awe that ignites my mind and fuels further travels into the much-welcomed shadowy soup. If it were a smooth journey, if my straying were easy, there would likely be something amiss.

To set the stage for what follows I shall tell you a little bit about who I am and what I do. The brevity of my introduction is a result not so much of limited space as of limited knowledge of who I am. I have a good take on what I do, and while I am not sure about whether I existed before I was born or what will become of me after I die, I am assuming that I exist now, hence the when question will not be considered further. Concerning where I am, it will become clear that I view myself_l-at once as an embodied and emergent being.

So, when people ask me who I am, I tell them that I am a human being first, and an ethologist second. I do not define who I am by what I do (although I do love what I do). I have discovered that animals play a large role in my defining my place in the world. As I journey into spiritual dimensions and use knowledge of the lives of other animals in their own worlds as a guide, I discover much about my own nature and about human nature. I can only assume that some of what I discover about my own place in this aweinspiring, mysterious, and wondrous world is related to the experience of other human beings. My own travels—spirited adventures for the most part-have been at times smooth, at times difficult and troubling, but they have been delightfully and incredibly rewarding and transforming, for they have opened the doors of my heart and all of my senses to the lives of others.

I have discovered that my own nature and spirituality (and consciousness and sociality) as a transient visitor to Earth are dynamically embodied in who I am and also are defined by emergent relationships with other beings. I have come to believe that all beings are defined as a combination of who is "in here"-in their own hearts and heads-and "out there"-in the social matrix of the external world. I-my spirituality, consciousness and soul-am truly a mysterious social phenomenon who does not live in isolation from others, animate or inanimate. (For discussion of the notion of distributed cognition, the possibility of there being dynamic external, interpersonal, and supraindividual psychological states that change over time, see Forster in press.)

While I believe that embodiment and emergence each play a role in bringing about self-unity, a sense of an integrated self, I also see that the relationships between the "in here" and the "out there" are not so cleanly separated. The social matrix in which I am defined is truly an integrated tapestry, a dynamic event of monumental proportions that may in the end resist being totally intelligible given the evolutionary state 
of my own (and other humans') brains. If the truth be told, often I am amazed by how simple it all seems, and equally often I am astounded by how complex it all is. Suffice it to say that my travels on the diverse and multidimensional landscape in which science and spirituality are actively and intimately intertwined have been the most valuable experiences in my peripatetic existence. Of this I am sure.

\section{DEEP ETHOLOGY AND MINDING ANIMALS}

In my own research on social behavior and behavioral ecology, I stress evolutionary, ecological, and developmental (ontogenetic) perspectives, and I try to understand individual differences within species and variations among species. Variation is not noise to be dispensed with but rather information that highlights just how different individuals, even closely related individuals, can be. My approach is called the "comparative approach to the study of behavior." I have done much interdisciplinary work, and I am a pluralist. While we know much about the lives of other animals, there remain enormous gaps in our knowledge that need to be filled before we can make any hard and fast general claims about the evolution of most behavior patterns. Caution is the best road to take.

I also work at different levels of analysis. While much of my research is done at the micro level (for example, analyzing frame-by-frame films of animals at play or animals looking out for potential predators), I am an interdisciplinary holist at heart. I prefer to tackle "big" questions. I also do not shy away from conducting detailed statistical analyses, but never do the animals I am studying get thrown aside as numbers, unnamed variables in an equation, or points on a graph. It is important that the "protective membrane of statistics" (Randour 2000, xvii) not shield us from the worlds of other animals-their joys and pains, their wisdom, their otherness.

I also identify and empathize with the animals I study. I developed the idea of "minding animals" a few years ago (Bekoff 1998a, b, c). Basically, the phrase "minding animals" means two things. First, it refers to caring for other animal beings, respecting them for who they are, appreciating their own worldviews, and wondering what and how they feel and why. Second, it refers to the fact that many animals have very active and thoughtful minds. I call myself a deep ethologist. I, as the "seer," try to become the "seen." I become coyote, I become penguin (I also become tree, and often I become rock). I name my animal friends and try to step into their sensory and motor worlds to discover what they might be like, how they sense their surroundings, and how they move about and behave in certain situations.

\section{THE USE OF ANIMALS BY HUMANS}

I am deeply concerned with the nature and asymmetry of human-animal interactions from theoretical and practical perspectives (Bekoff 1998a, b, c; Bekoff in press), specifically the anthropocentric use of animals that usually is justified by some form of a utilitarian calculus in which human benefits are traded off against costs to the animal. When the benefits outweigh the costs, animal use is justified. I also am interested in questions of how humans should live with wild nature.

I am a patient and compassionate activist who believes that "getting my hands dirty," getting out there and showing people the horrible things we do to far too many animals, is the best way to make longlasting changes in their hearts and heads. (For a wonderful discussion of the trials and tribulations of activism and also of its innumerable fruits, see Hill 2000.) Indifference is deadly. My activism centers on getting people to think and to tell me why they think, feel, and act in the ways they do.

As an unwavering dreamer and optimist, I often feel victimized by hope. Nonetheless, it is my dream that changes in attitude and heart will ultimately bring forth harmony in the relationships between animals and humans, for nonhuman animals will forever be competing with humans, their dominant, big-brained, 
mammalian kin. The animals are likely to lose most of these encounters as humans continue to try to redecorate (manage, control) nature for their own ends.

Activism for animals has helped me tap into my own spirituality, for there are numerous costs to activism - harassment, intimidation, humiliation, and frustration - that often become personal. I have felt the effects of attempts to silence my questions about the reintroduction of Canadian lynx into Colorado as well as my questioning why dogs had to be killed in physiology courses in medical school for students to learn about life. Such assaults made me dig deeply into my heart in my efforts to understand and to explain to others why I was doing what I was doing, whether it was organizing protests to save animals or partaking in candlelight vigils and prayer services for animals who had been killed. Suffice it to say that compassionate people who push the envelope can easily engender the wrath of others.

One belief that drives me is that every individual counts and that every individual makes a difference. As Margaret Mead noted, "Never doubt that a small group of thoughtful, committed citizens can change the world. Indeed, it is the only thing that ever has." Creative proactive solutions drenched in deep humility, compassion, caring, respect, and love need to be developed to deal with the broad range of problems with which we are currently confronted. Activism often underlies their formulation and implementation.

\section{SCIENCE AND THE PRESUMPTION OF OMNISCIENCE}

Why say "fantastic" when you mean "Scientific"? (e e cummings 1953, 105)

Back off man, I'm a scientist. (Harold Ramis, as the scientist in the movie Ghost Busters)

A clear distinction should be made between what is not found by science and what is found to be non-existent by science. What science finds to be non-existent, we must accept as non-existent; but what science merely does not find is a completely different matter. . . . It is quite clear that there are many, many mysterious things. (the Dalai Lama 1999, 9)

While science has much to offer, science does not have a monopoly on truth. There are many ways of knowing. Scientists sometimes parade about as know-it-alls, afraid to utter "I don't know." The presumption of omniscience not only precludes learning about much of the mystery and awe of the natural world, but it also presents the big business of science as an arrogant and authoritarian enterprise that offends nonscientists. A lack of knowledge often is presented to mean that something cannot or does not exist, end of story. So, for example, while science cannot prove the existence of God, it cannot prove that God does not exist. Science also cannot prove that animals have deep emotional lives or souls, but it also cannot prove that they do not. Often science discounts possibilities in the absence of data. I find this to be paradoxical and illogical, for just because we do not know many of the details of how, for example, science, spirituality, religion, and God are associated with one another, this is not to say that they are not intimately interconnected.

Nowadays many people, including some scientists, question science. But some famous scientists in the past (Albert Einstein, Alfred Russell Wallace, William James) also warned against the dangers of scientism (Lorimer 1999; see many of the essays in this book for discussions of the dangers of narrow scientism). I myself question the dogma of science and, as a member of the academy, I am often embarrassed by the arrogance of some of my colleagues. Increasingly science is seen not as a selfjustifying activity but as another institution whose claims on the public treasury must be defended (Bekoff and Jamieson 1996; Bekoff 2000a). Nonscientists are generally more aware and more inquisitive, and society is more complex. There needs to be a new social contract between science and society that is characterized by two-way dialogue (Gibbons 1999). Science will continually have to be legitimized. Thus 
the dialogue will have to go two ways-science to society and society to science. Scientists have numerous and deep social responsibilities that can no longer be ignored (Mackey 1999; Bekoff 2000a). Those who question science are not being anti-science, anti-intellectual, or Luddites. Rather, there is increasing skepticism because critics feel that, given the enormous amount of money that has gone into various scientific endeavors, science has not delivered the goods: few final and irrefutable answers are available. Many are also concerned with the politics, economics (rush for patents, financial gains), and arrogance of science. While we are certainly making some progress in living in harmony with other animals and inanimate landscapes, we are nowhere near to achieving a high grade in these encounters.

\section{SCIENCE, SPIRITUALITY, AND SOUL}

Holmes Rolston, III $(1999,161)$ notes that "science cannot tell humans what they most need to know: the meaning of life and how to value it." Science does not allow for expressions of sentimentality or spirituality. Unchecked, science can easily produce a soulless society and a loss of human dignity and free will. Questioning science and recognizing the limitations of scientism will make for better science by situating it in relation to other fields of inquiry in which it is more acceptable to ponder questions about spirituality, soul, life, death, God, and love. (For an illuminating discussion see Smith 2001.)

Huston Smith (2001) argues that while science surely discovers many facts about the world, science has not discovered facts that discount a religious worldview. Furthermore, Smith argues that scientism has contributed to a predicament of the human spirit by placing science on a pedestal above and beyond religious worldviews in which talk about spirituality, soul, and God are allowed. Science also reduces (often arrogantly with misplaced autonomy and authority) the mystery, magic, and awe of life to "facts" contained in equations and graphs that are devoid of spirit and soul. I believe Smith is correct to claim that science is not necessarily the culprit but rather "our misconstrual of it" (p. 5).

Dichotomies and dualisms need to be challenged and dissolved if we are to make progress in bringing together science, spirituality, and religion. Supposedly objective scientists need not be suspicious of subjective and more compassionate inquiries into human nature or of things they cannot understand or control. Of course, science is not value free, for scientists, after all, are only human. We need to unpack the blocks that predispose us to think that something cannot be so just because science says that it cannot be so. A pluralistic and open view will help get us past speciesism. Some blocks are built into the standard educational process, others in scientific and religious worldviews. Few scientists come out of the closet, and this is unfortunate, for I truly believe that there are many more pluralists than is obvious. A new paradigm in which science and spirituality are viewed as equals will allow for the development of a deep sense of unity and kinship, the formation and maintenance of deep and meaningful interconnections among all animals and all life. I envision a seamless tapestry of oneness, a unity of communities in which we are all one, the seer and the seen.

\section{THE IMPORTANCE OF INTERDISCIPLINARY COOPERATION: THE EVOLUTION OF SOCIAL MORALITY}

There are many areas in which scientists such as myself can pursue interesting and important questions that center on human spirituality and the place of humans in the world. One such area concerns the evolution of social morality. People often wonder if some animals have codes of social conduct that regulate their behavior in terms of what is permissible and what is not permissible during social encounters. They want to know just what are the moral capacities of animals-are they moral agents with a moral sense who are able to live in moral communities? In a recent issue of Journal of Consciousness Studies (vol. 7, no. 1/2, 2000), researchers from many disciplines debated the evolutionary origins of morality. These scholars were interested in discussing animal roots on which human morality might be 
built, even if it is not identical to animal morality. Charles Darwin's (1859; [1872] 1998) ideas about evolutionary continuity, that behavioral, cognitive, emotional, and moral variations among different species are differences in degree rather than in kind, are often invoked in such exercises. Thus, this view argues that there are shades of gray among different animals and between nonhumans and humans, that the differences are not black and white with no transition stages or inexplicable jumps (Gruen in press; Güzeldere and Nahmias in press; see also many other essays in Bekoff, Allen, and Burghardt in press). There is not a void in the evolution of moral capacity or agency. Current work in evolutionary biology and anthropology suggests that linear scales of evolution in which there are large gaps between humans and at least some animals are simplistic views of the evolutionary process. Further, as I will discuss below, models and explanations that exclude group selection in deference to individual selection also need to be revised.

The study of the evolution of morality, specifically cooperation and fairness, is closely linked to science, religion, theology, spirituality, and perhaps even different notions of God, in that ideas about continuity and discontinuity (the possible uniqueness of humans and other species), individuality, and freedom need to be considered in detail. Furthermore, it is important to discuss relationships between science, religion, and God, because spirituality and the notion of one form of God or another had strong influences on the evolution of our ancestors and their cognitive, emotional, and moral lives.

Recently, Gregory Peterson (2000; see also Peterson 1999) has pondered the evolutionary roots of morality (stages that he refers to as "quasi-morality" and "proto-morality" in animals) and religion in relation to the roles played by cognition and culture. He also has stressed the importance of recognizing continuities and discontinuities with other animals, arguing ultimately (and speciesistically) that while some animals might possess proto-morality (they are able "to rationally deliberate actions and their consequences" [2000, 475]), none other than humans is "genuinely moral," because to be able to be genuinely moral requires higher emergent levels of cognition as well as culture and the worldview that culture provides, namely, religion. Peterson claims that "Quasi-moral and proto-moral systems do not require a global framework that guides decision making. They are always proximate and pragmatic. In these systems, there is no long-term goal or ideal state to be achieved. Yet, genuine morality is virtually inconceivable without such conceptions" $(2000,478)$.

Peterson also claims that any sociobiological account (based on selfishness or combativeness) of human morality is incomplete. I agree and also argue that this is so for some nonhuman animals as well. To be sure, Peterson's views are very stimulating. I will not go into detail here, but suffice it to say, and I hope that it becomes clear later on, that when animals are studied in their own worlds they may indeed be found to have their own form of genuine morality, and there might indeed be long-term goals and ideal states to be achieved. Our anthropocentric view of other animals, in which humans are so taken with themselves, is far too narrow. The worlds and lives of other animals are not identical to those of humans and may vary from species to species and even within species. The same problems arise in the study of emotions if we believe that emotions in animals are going to be identical to or even recognizably similar among different species. There is also variability among humans in what some might view as long-term goals and ideal states, and it would of course be premature to conclude that there is one set of long-term goals and ideal states that characterize, or are essential to, the capacity to be genuinely moral. We really are not experts about ourselves. To view stages of moral evolution as Peterson does, it looks like quasimorality and proto-morality are less than genuine morality. This view could lead to linear hierarchical views of evolution, whether or not it is Peterson's intent to go this route.

Evolutionary reconstructions of social behavior often depend on educated guesses, some better than others, about the past social (and other) environments in which ancestral beings lived. Evolution is "private" as are others' minds. Often it is difficult to know with a great deal of certainty very much about 
how different variables have figured into evolutionary scenarios. It is an understatement to note that is extremely difficult to study the evolution of morality in any animal species, and the very notion of animal morality itself often makes for heated discussions. Irwin Bernstein's concern that "morality in animals might lie outside of the realm of measurement techniques available to science" $(2000,34)$ needs to be taken seriously. Nonetheless, it seems clear that detailed comparative analyses of social behavior in animals can indeed provide insights into the evolution of social morality. To be sure, these sorts of studies are extremely challenging, but the knowledge that is gained is essential if we are to learn more about the evolution of sociality and social morality, and about human nature and perhaps human uniqueness.

Many discussions of the evolution of morality center on the development of various sorts of models (Axelrod 1984; Ridley 1996; Skyrms 1996; Dugatkin 1997; Sober and Wilson 1998; 2000; see also essays in Journal of Consciousness Studies, vol. 7, no. 1/2, 2000). While these models are very useful for stimulating discussion and further research, they do not substitute for available data (however few) that may bear on animal morality (see, for example, some essays in Aureli and de Waal [2000] for additional comparative information).

Here I briefly discuss some comparative data on social play behavior in hope of broadening the array of species in which researchers attempt to study animal morality. I am specifically concerned with the notion of "behaving fairly." By this I mean the notion that animals often have social expectations when they engage in various sorts of social encounters the violation of which constitutes being treated unfairly because of a lapse in social etiquette. I will elaborate later in my discussion of social play behavior (much of the following is from Bekoff 2001).

I also argue that it is through social cooperation that groups (communities) are built from individuals agreeing to work in harmony with other individuals. Whether or not individuals lose various freedoms when balanced against the benefits that accrue when they work for the good of a group is unknown and needs to be studied more carefully in various species.

Cooperation and Fairness. In my view, cooperation is not always merely a by-product of tempering aggressive and selfish tendencies (combating Richard Dawkins's selfish genes) and attempts at reconciliation. Rather, cooperation and fairness can evolve on their own because they are important in the formation and maintenance of social relationships. This view, in which nature is sanitized, contrasts with that of those who see aggression, cheating, selfishness, and perhaps amorality as driving the evolution of sociality. The combative Hobbesian world in which individuals are constantly at one another's throats is not the natural state of affairs, nature is not always "red in tooth and claw," and altruism is not always simply selfishness disguised.

Does It Feel Good to Be Fair? It is important to consider the possibility that it feels good to be nice to others, to cooperate with them, to treat them fairly, and to forgive them for their mistakes and shortcomings. Thus, studies of the evolution of social morality also need to consider the rich cognitive ("intellectual") and deep emotional lives of other animals (Bekoff 2000b, c). Skeptical dismissals that animals are nothing but non-sentient automatons are dead ends. Skeptics need to share the burden of proof with those who claim that some animals have highly evolved passionate natures. While one cannot prove without doubt that some animals have rich emotional lives, it also is impossible to prove that they do not.

\section{SPECIESISM AND THE TAXONOMIC DISTRIBUTION OF MORAL CAPACITY: THE IMPORTANCE OF STUDYING SOCIAL CARNIVORES}


Currently we simply do not have enough data to make hard and fast claims about the taxonomic distribution among different species of the cognitive skills and emotional capacities necessary for being able to empathize with others, to behave fairly, or to be moral agents. Recently, Peter Marler $(1996,22)$ concluded his review of social cognition in nonhuman primates and birds as follows: "I am driven to conclude, at least provisionally, that there are more similarities than differences between birds and primates. Each taxon has significant advantages that the other lacks." Michael Tomasello and Josep Call (1997, 399-400) summarized their comprehensive review of primate cognition by noting that "The experimental foundation for claims that apes are 'more intelligent' than monkeys is not a solid one, and there are few if any naturalistic observations that would substantiate such broad-based, species-general claims." While J. C. Flack and Frans de Waal's (2000) and others' focus is on nonhuman primates as the most likely animals to show precursors to human morality, others have argued that we might learn as much or more about the evolution of human social behavior by studying social carnivores (Schaller and Lowther 1969; Tinbergen 1972; Thompson 1975), species whose social behavior and organization resemble that of early hominids in a number of ways-divisions of labor, food sharing, care of young, and inter- and intrasexual dominance hierarchies.

What we really need are long-term field studies of social animals for which it would be reasonable to hypothesize that emotions and morality have played a role in the evolution of sociality, that emotions and morality are important in the development and maintenance of social bonds that allow individuals to work together for the benefit of all group members (see also Gruen in press). Stories about wild animals are also important for informing us about what they do in the course of their life cycles (Bekoff 2000b, c). Here is a short story, one among many, that made me think hard about the life of the other animals with whom I share my home.

A Lion, a Fox, and a Funeral. I recently saw a female fox bury a male fox. One morning when I went out to hike with my companion dog, Jethro, I looked down the road and saw a female red fox seemingly trying to cover the carcass of a red fox who had been killed by a mountain lion two days earlier. I was fascinated, for she was deliberately orienting her body so that when she kicked debris with her hind legs it would cover the carcass. There has been a family of foxes near my house for almost a decade, and I assume that she was the mate or a close relative of the deceased. She would kick dirt, stop, look at the carcass, and intentionally kick again. I observed this "ritual" for about 20 seconds. A few hours later I went to see the carcass, and it was totally buried.

No one to whom I have spoken, naturalists or professional biologists, has ever seen a red fox bury another red fox. I do not know if the female fox was intentionally trying to bury her friend, but there is no reason to assume she was not. Perhaps she was grieving (as do domestic dogs, elephants, chimpanzees, and other animals; Bekoff 2000b) and I was observing a fox funeral. There is no doubt that foxes and other animals have deep emotional lives. In 1947 a naturalist on the East coast saw a male fox lick his mate as she lay dead (Comstock 1947). He also vigorously protected her.

I was lucky to have this encounter, for nature does not hold court at our convenience. Much happens in the complex lives of animals to which we are not privy, but when we are fortunate to see animals at work, how splendid it is. (Long live natural history!) Naturalistic studies, often thought to be "soft science," need not be casualties of "hard" science. Anton Moser (2000) discusses how "soft" and "hard" sciences can be unified to produce "deep science" in which aesthetic and sentient experiences are merged with deduction, induction, and conventional scientific practices. The "true," the "right," and the "beautiful" are integrated to produce a richer view of the beauty of science. Later I will return to the importance of ethological field studies, considered by some to be soft science but which form the basis for any theory about animal behavior and how animals may provide information about our own spirituality. 
I mention the fox story because a number of people expressed skepticism (claiming speciesistically, but perhaps unbeknownst to them) when I told them I had been observing a fox. When I asked them if they would have had a different attitude if the fox had been a chimpanzee (for example), some said yes, they might then entertain the notion that the survivor was grieving. One person told me that she would even speculate about the religious experience that might have been felt by the survivor if she had been a primate, but surely not a fox.

\section{ANIMAL PLAY: LESSONS IN COOPERATION, FAIRNESS, SPIRIT, AND SOUL}

"Happiness is never better exhibited than by young animals, such as puppies, kittens, lambs, \&c., when playing together, like our own children." So wrote Charles Darwin in his book The Descent of Man and Selection in Relation to Sex ([1871] 1936, 448).

Animal play is obvious, but animal social morality is not. (For definitions of social play see Bekoff and Byers 1981; 1998; Fagen 1981; Power 2000; Burghardt in press.) Social play in animals is an exhilarating activity in which to engage and to observe. The rhythm, dance, and spirit of animals at play is incredibly contagious. Not only do their animal friends want to join in or find others with whom to romp, but I also want to play when I see animals chasing one another, playing hide-and-seek, and wrestling with reckless abandon. My body once tingled with delight as I watched a young elk in Rocky Mountain National Park, Colorado, running across a snow field, jumping in the air and twisting his body while in flight, stopping to catch his breath, and then jumping and twisting over and over and again. There was plenty of grassy terrain around, but he had chosen the snow field. Buffaloes will follow one another and playfully run onto and slide across ice, excitedly bellowing "Gwaaa" as they do so. Dogs and cats love to play, as do many other mammals. Birds playfully soar across the sky, chasing, diving here and there, and frolicking with one another.

I think of play as being characterized by what I call the "Five S's of Play," its Spirit, Symmetry, Synchrony, Sacredness, and Soulfulness. The Spirit of play is laid bare for all to see as animals run about, wrestle, and knock one another over. The Symmetry and Synchrony of play are reflected in the harmony of the mutual agreements to trust one another-individuals seem to share intentions to cooperate with one another to prevent play from spilling over into fighting. This trust is Sacred. Finally, there is a deepness to animal play in that the players are so immersed in play that they are the play. Play is thus a Soulful activity, perhaps the essence of individuals' being at the moment as they play from deep in their hearts. Play is about being; there are no whys in play.

There also is a feeling of incredible freedom and creativity in the flow of play. So it is important also to keep in mind the six F's of play: Flexibility, Freedom, Friendship, Frolic, Fun, and Flow. As they run about, jump on one another, somersault, and bite one another, animals create confusing scenarios. Behavior patterns that are observed in mating are intermixed in flexible kaleidoscopic sequences with actions that are used during fighting, looking for prey, and avoiding being eaten.

The unmistakable emotions associated with play-joy and happiness—drive animals to become at one with the activity. One way to get animals (including humans) to do something is to make it fun, and there is no doubt that animals enjoy playing. Studies of the chemistry of play support the claim that play is fun. Dopamine (and perhaps serotonin and norepinephrine) are important in the regulation of play. Rats show an increase in dopamine activity when anticipating the opportunity to play (Siviy 1998), and they enjoy 
being playfully tickled (Panksepp 2000). There is also a close association between opiates and play (Panksepp 1998).

Neurobiological data are essential for learning more about whether play truly is a subjectively pleasurable activity for animals as it seems to be for humans. Siviy's and Panksepp's findings suggest that it is. In light of these neurobiological (hard) data concerning possible neurochemical bases for various moods, in this case joy and pleasure, skeptics who claim that animals do not feel emotions might be more likely to accept the idea that enjoyment could well be a motivator for play behavior.

How Do Animals Tell Others "I Want to Play with You?" When individuals play, they typically use action patterns that are also used in other contexts, such as predatory behavior, antipredatory behavior, and mating. These actions may not vary much across different contexts, or they may be hard to discriminate even for the participants. How do animals know that they are playing? How do they communicate their desires or intentions to play or to continue to play? How is the play mood maintained?

Because there is a chance that various behaviors during ongoing social play can be misinterpreted, individuals need to tell others, "I want to play," "this is still play no matter what I am going to do to you," or "this is still play regardless of what I just did to you." An agreement to play rather than fight, mate, or engage in predatory activities can be negotiated in various ways. Individuals may use various behavior patterns_-play markers_to initiate play or to maintain a play mood (Bekoff 1975; 1977a; 1995; Bekoff and Allen 1992; 1998; Allen and Bekoff 1997) by punctuating play sequences with these actions when it is likely that a particular behavior may have been, or will be, misinterpreted. It is also possible that there are auditory, olfactory, and tactile play markers (Bekoff and Byers 1981; Fagen 1981). I found that a play signal called a "bow" in infant canids (domestic dogs, wolves, and coyotes) was used nonrandomly, especially when biting accompanied by rapid side-to-side shaking of the head was performed (Bekoff 1995). Biting accompanied by rapid side-to-side shaking of the head is performed during serious aggressive and predatory encounters and can easily be misinterpreted if its meaning is not modified by a play signal. There also is little evidence that play signals are used to deceive others in canids or other species. Cheaters are unlikely to be chosen as play partners because others can simply refuse to play with them (I thank David Sloan Wilson for making this point) and choose others. Personal observations of infant coyotes show that cheaters have difficulty getting other young coyotes to play. It is not known if individuals select play partners based on what they have observed during play by others.

Individuals might also know that they are playing because the actions that are performed differ when they are performed during play as compared to other contexts (Hill and Bekoff 1977), or the order in which motor patterns are performed differs from and might be more variable than the order in which they are performed during, for example, serious aggressive, predatory, or reproductive activities (Bekoff and Byers 1981).

Individuals also engage in role reversing and self handicapping (Bekoff and Allen, 1998) to maintain social play. Each can serve to reduce asymmetries between the interacting animals and foster the reciprocity that is needed for play to occur. Self handicapping happens when an individual behaves in a pattern that might compromise her. For example, a coyote might not bite her play partner as hard as she can, or she might not play as vigorously as she can. Duncan M. Watson and David B. Croft (1996) found that red-neck wallabies adjusted their play to the age of their partner. When a partner was younger, the older animal adopted a defensive, flatfooted posture, and pawing rather than sparring occurred. In addition, the older player was more tolerant of its partner's tactics and took the initiative in prolonging interactions. 
Role reversing occurs when a dominant animal performs an action during play that would not normally occur during real aggression. For example, a dominant animal might not voluntarily roll over on his back during fighting but would do so while playing. In some instances role reversing and self handicapping might occur together. For example, a dominant individual might roll over while playing with a subordinate animal and inhibit the intensity of a bite. From a functional perspective, self handicapping and role reversing, similar to using specific play invitation signals or altering behavioral sequences, might signal an individual's intention to continue to play.

Fine-Tuning Play: Why Cooperate and Play Fairly? For years I tried to figure out why play evolved as it did. Why do animals carefully use play signals to tell others that they really want to play and not try to dominate them, and why do they engage in self handicapping and role reversing? One morning, while hiking with Jethro, I had one of those "aha" experiences, and the puzzle was solved. It dawned on me that during social play, while individuals are in a relatively safe environment, they learn ground rules that are acceptable to others-how hard they can bite, how roughly they can interact-and how to resolve conflicts. There is a premium on playing fairly and trusting others to do so as well. There are codes of social conduct that regulate actions that are and are not permissible, and the existence of these codes likely speak to the evolution of social morality. What could be a better atmosphere in which to learn social skills than during social play, where there are few penalties for transgressions? Individuals might also generalize codes of conduct learned in playing with specific individuals to other group members and to other situations such as sharing food, defending resources, grooming, and giving care. (Social morality does not mean other animals are behaving unfairly when they kill for food, for example, for they have evolved to do this.)

Playtime generally is safe time-transgressions and mistakes are forgiven and apologies are accepted by others especially when one player is a youngster who is not yet a competitor for social status, food, or mates. There is a certain innocence or ingenuousness in play. Individuals must cooperate with one another when they play - they must negotiate agreements to play (Bekoff 1995). Robert Fagen (1993, 192) noted that "Levels of cooperation in play of juvenile primates may exceed those predicted by simple evolutionary arguments. ..." The highly cooperative nature of play has evolved in many other species (Fagen 1981; Bekoff 1995; Bekoff and Allen 1998; Power 2000; Burghardt in press). Detailed studies of play in various species indicate that individuals trust others to maintain the rules of the game (Bekoff and Byers 1998). While there have been numerous discussions of cooperative behavior in animals (e.g., Axelrod 1984; Ridley 1996; Dugatkin 1997; essays in Journal of Consciousness Studies, vol. 7, no. 1/2, 2000 , and references therein), none has considered social play-the requirement for cooperation and reciprocity—and its possible role in the evolution of social morality, namely, behaving fairly.

Individuals of different species seem to fine-tune ongoing play sequences to maintain a play mood and to prevent play from escalating into real aggression. Detailed analyses of film show that in canids there are subtle and fleeting movements and rapid exchanges of eye contact that suggest that players are exchanging information on the run, from moment to moment, to make certain everything is all right-that this is still play. Owen Aldis (1975) suggested that in play, there is a 50:50 rule so that each player "wins" about 50 percent of their play bouts by adjusting their behavior to accomplish this (for further discussion and details on rodent play, see Pellis in press).

Why might animals fine-tune play? While play in most species does not take up much time and energy (Bekoff and Byers 1998; Power 2000), and in some species only minimal amounts of social play during short windows of time early in development are necessary to produce socialized individuals (two 20minute play sessions with another dog, twice a week, are sufficient for domestic dogs from three to seven weeks of age [Scott and Fuller 1965]), researchers agree that play is very important in social, cognitive, and/or physical development and may also be important for training youngsters for unexpected 
circumstances (Spinka, Newberry, and Bekoff 2001). While there are few data concerning the actual benefits of social play in terms of survival and reproductive success, it generally is assumed that shortterm and long-term functions (benefits) vary from species to species and among different age groups and between the sexes within a species. No matter what the functions of play may be, there seems to be little doubt that play has some benefits and that the absence of play can have devastating effects on social development (Power 2000; Burghardt in press).

During early development there is a small time window when individuals can play without being responsible for their own well-being. This time period is generally referred to as the socialization period, for this is when species-typical social skills are learned most rapidly. It is important for all individuals to engage in at least some play, and there is a premium for playing fairly if one is to be able to play at all. If individuals do not play fairly they may not be able to find willing play partners. In many species individuals also show play-partner preferences and it is possible that these preferences are based on the trust that individuals place in one another.

Levels of Selection. Following the lines of Sober and Wilson's discussion (1998, 135ff.) concerning the choice of social partners, it may be that behaving fairly is a group adaptation, but once a social norm evolves it becomes individually advantageous to behave fairly. We still need to figure out how to test extant ideas about levels of selection-group selection "versus" individual selection-and studies of the evolution of social morality are good places to focus for expanding our views (e.g., Boehm 1999; Leigh 1999; see also Aviles 1999; Bradley 1999; Gould and Lloyd 1999; Kitchen and Packer 1999; Mayr 2000).

The Evolution of Fairness: A Game-Theoretical Model. A recent game-theoretic model (Dugatkin and Bekoff forthcoming) analyzed four possible strategies that an individual could adopt over time (for species in which fairness can be expressed during two different developmental stages): being fair $(F)$ and at a later date being fair (F/F), being fair and then not fair (F/NF), being not fair and then fair (NF/F), and being not fair and then not fair (NF/NF). Of these, only F/F and NF/F were Evolutionarily Stable Strategies (ESSes) that could evolve under the conditions of the model. Always acting fairly should be much more common than never acting fairly. Furthermore, and perhaps of greater interest, our model predicts that while fairness later in development can exist without fair play early on (NF/F is an ESS), the converse, $F / N F$, is not true. Thus, we expect that should fairness be expressed early in life it should also be expressed later in life; however, it is possible that fairness later in life need not be preceded by earlier fairness. This idea is certainly testable in principle by following identified individuals and recording how they distribute fairness across different activities as they mature.

That F/NF is not an ESS is of interest, because this strategy could be conceived as a form of deceit. This finding fits in well with what is known about play signals, for, as I mentioned above, there is little evidence that play signals are used to deceive others at any stage of development (Bekoff 1977a; Bekoff and Allen 1998).

\section{NEUROBIOLOGICAL BASES OF SHARING INTENTIONS AND MIND READING}

We can now ask, How might a play bow (or other action) serve to provide information to its recipient about the sender's intentions? Is there a relationship between acting, feeling, seeing, and feeling/knowing? Perhaps one's own experiences with play can promote learning about the intentions of others. Perhaps the recipient shares the intentions (beliefs, desires) of the sender based on the recipient's own prior experiences of situations in which she performed play bows. Recent research suggests a neurobiological basis for sharing intentions. Mirror neurons, found in macaques, fire when a monkey executes an action and also when the monkey observes the same action performed by another monkey (Gallese 1998; Gallese and Goldman 1998; Motluk, 2001). 
Research on mirror neurons is truly exciting, and the results of these efforts will be very helpful for answering questions about which species of animals may have "theories of mind" or "cognitive empathy" about the mental and emotional states of others. Vittorio Gallese and philosopher Alvin Goldman (1998, 493) suggest that mirror neurons might "enable an organism to detect certain mental states of observed conspecifics . . . as part of, or a precursor to, a more general mind-reading ability." Laurie Carr and her colleagues at The University of California at Los Angeles discovered, by using neuroimaging in humans, similar patterns of neural activation both when an individual observed a facial expression depicting an emotion and when he or she imitated the facial expression. This research suggests a neurobiological underpinning of empathy. Chris and Uta Frith (1999) report the results of neural imaging studies in humans that suggest a neural basis for one form of "social intelligence," understanding others' mental states (mental state attribution).

More comparative data are needed to determine if mirror neurons (or functional equivalents) are found in other taxa and if they might actually play a role in the sharing of intentions or feelings-perhaps keys to empathy-between individuals engaged in an ongoing social interaction such as play. Neuroimaging studies will also be useful.

\section{SOCIAL PLAY AND SOCIAL MORALITY: WHERE TO FROM HERE?}

To stimulate further comparative research (and the development of models) on a wider array of species than has previously been studied, I offer the hypothesis that social morality, in this case behaving fairly, is an adaptation that is shared by many mammals, not only by nonhuman and human primates. Behaving fairly evolved because it helped young animals acquire social and other skills needed as they matured into adults. A focus on social cooperation is needed to balance the plethora of research that is devoted to social competition and selfishness (for further discussion see Boehm 1999 and Singer 1999).

Group-living animals may provide many insights into animal morality. In many social groups individuals develop and maintain tight social bonds that help to regulate social behavior. Individuals coordinate their behavior-some mate, some hunt, some defend resources, some accept subordinate status-to achieve common goals and to maintain social stability. Consider pack-living wolves. For a long time researchers thought pack size was regulated by available food resources. Wolves typically feed on such prey as elk and moose, each of which is larger than an individual wolf. Successfully hunting such large ungulates takes more than one wolf, so it made sense to postulate that wolf packs evolved because of the size of wolves' prey. Defending food might also be associated with pack-living. However, long-term research by David Mech (1970) showed that pack size in wolves was regulated by social, not food-related, factors. Mech discovered that the number of wolves who could live together in a coordinated pack was governed by the number of wolves with whom individuals could closely bond ("social attraction factor") balanced against the number of individuals from whom an individual could tolerate competition ("social competition factor"). Codes of conduct and packs broke down when there were too many wolves. Whether or not the dissolution of packs resulted from individuals behaving unfairly is unknown, but this would be a valuable topic for future research with wolves and other social animals.

In social groups, individuals often learn what they can and cannot do, and the group's integrity depends upon individuals agreeing that certain rules regulate their behavior. At any given moment individuals know their place or role and that of other group members. As a result of lessons in social cognition and empathy that are offered in social play, individuals learn what is "right" or "wrong"-what is acceptable to others-the result of which is the development and maintenance of a social group that operates efficiently. The absence of social structure and boundaries can produce gaps in morality that lead to the dissolution of a group (Bruce Gottlieb, personal communication). 
In summary, I argue that mammalian social play is a useful behavioral phenotype on which to concentrate in order to learn more about the evolution of fairness and social morality. (While birds and individuals of other species engage in social play, there are too few data from which to draw detailed conclusions about the nature of their play.) There is strong selection for playing fairly because individuals benefit from adopting this behavioral strategy. Numerous mechanisms (play invitation signals, variations in the sequencing of actions performed during play when compared to other contexts, self handicapping, role reversing) have evolved to facilitate the initiation and maintenance of social play in numerous mammalsto keep others engaged-so that agreeing to play fairly and the resulting benefits of doing so can be readily achieved. Mark Ridley (1996) points out that humans seem to be inordinately upset about unfairness, but we do not know much about other animals' reaction to unfairness. He suggests that perhaps behaving fairly pays off in the long run. Our model (Dugatkin and Bekoff forthcoming) suggests that it might.

Future comparative research that considers the nature and details of the social exchanges that are needed for animals to engage in play-reciprocity and cooperation-will undoubtedly produce data that bear on the questions I raise in this essay and also help to "operationalize" the notion of behaving fairly by informing us about what sorts of evidence confirm that animals are behaving with some sense of fairness. In the absence of this information it is premature to dismiss the possibility that social play has some role in the evolution of fairness and social morality, or to assert that animals other than primates are unable intentionally to choose to behave fairly because they lack the necessary cognitive skills or emotional capacities. These are empirical questions for which the comparative data base is scant.

Lori Gruen (in press) points out that we still need to come to terms with what it means to be moral. She also suggests that we need to find out what cognitive and emotional capacities operate when humans perform various moral actions, and to study animals to determine if they share these capacities or some variation of them. Even if it were the case that available data suggested that nonhuman primates do not seem to behave in a specific way, for example, playing fairly, in the absence of comparative data this does not justify the claim that individuals of other taxa cannot play fairly. ${ }^{1}$

Learning about the taxonomic distribution of animal morality involves answering numerous and often difficult questions. Perhaps it will turn out that the best explanation for existing data in some taxa is that some individuals do indeed on some occasions modify their behavior to play fairly.

Play may be a unique category of behavior in that asymmetries are tolerated more than in other social contexts. Play cannot occur if the individuals choose not to engage in the activity, and the equality (or symmetry) needed for play to continue makes it different from other forms of seemingly cooperative behavior (e.g., hunting and caregiving). This sort of egalitarianism is thought to be a precondition for the evolution of social morality in humans. From whence did it arise? We really do not know much about the origins of egalitarianism. Armchair discussions, while important, will do little in comparison to our having direct experiences with other animals. In my view, studies of the evolution of social morality are among the most exciting and challenging projects that behavioral scientists (ethologists, geneticists, evolutionary biologists, neurobiologists, psychologists, anthropologists), theologians, and religious scholars face. We need to rise to the task before us rather than dismiss in a speciesistic manner the moral lives of other animals.

I have no doubt that studying and learning about animal play can teach us to live more compassionately with heart and love. Keep in mind the Spirit, Symmetry, Synchrony, Sacredness, and Soul of play. Learning about the evolution of cooperation, fairness, trust, and social morality goes well beyond traditional science and can be linked to religion, theology, and perhaps even to different notions of God, 
because ideas about continuity and discontinuity (the possible uniqueness of humans and other species) and individuality have to be taken into account.

\section{ANIMAL EMOTIONS: EXPLORING PASSIONATE NATURE}

It is hard to watch elephants' remarkable behavior during a family or bond group greeting ceremony, the birth of a new family member, a playful interaction, the mating of a relative, the rescue of a family member, or the arrival of a musth male, and not imagine that they feel very strong emotions which could be best described by words such as joy, happiness, love, feelings of friendship, exuberance, amusement, pleasure, compassion, relief, and respect. (Poole 1998, 90-91)

Do elephants feel joy, chimpanzees grief and depression, and dogs happiness and dejection? People disagree about the nature of animal emotions, especially concerning the question of whether any animals other than humans can feel emotions. Joyce Poole, who has studied elephants for more than two decades, believes that elephants have highly evolved emotional lives, and Greeks, long ago, believed that many animals experience the same range of emotions as humans. Current research, especially in ethology, neurobiology, endocrinology, psychology, and philosophy, is providing compelling evidence that at least some animals likely feel a full range of emotions, including fear, joy, happiness, shame, embarrassment, resentment, jealousy, rage, anger, love, pleasure, compassion, respect, relief, disgust, sadness, despair, and grief (for detailed discussions and long lists of references see Panksepp 1998 and Bekoff 2000b, c, d).

When we see animals express their emotions they are truly expressing their spirits and souls. In my book, The Smile of a Dolphin: Remarkable Accounts of Animal Emotions (2000b), many world-famous researchers who have spent their lives with a wide variety of animals shared their stories about the emotional lives of the animals they know best. Their stories, supported by copious amounts of data, leave no doubt as to whether many animals experience the deepest of emotions ranging from joyful glee when playing to bereavement, grief, and depression over the loss of a mate, child, or other friend. Animals may even fall in love. So, writes Bernd Heinrich in his book, Mind of the Raven (1999, 341): "Since ravens have long-term mates, I suspect that they fall in love like us, simply because some internal reward is required to maintain a long-term pair bond." Heinrich has studied and lived with ravens for many years and knows these wonderful birds well.

There have also been reports of animal emotions in the popular press, including newspapers and magazines. In one story, a troop of about one hundred rhesus monkeys in Tezpur, India, brought traffic to a halt after a baby monkey was hit by a car. The monkeys encircled the injured infant, whose hind legs were crushed and who lay in the road unable to move, and blocked all traffic. A government official reported that the monkeys were angry, and a local shopkeeper was quoted as saying, "It was very emotional . . . some of them massaged its legs. Finally, they left the scene carrying the injured baby with them."

In another incident, baboons in Saudi Arabia waited for three days on the side of a road to take revenge on a driver who had killed a member of their troop. The baboons lay in waiting and ambushed the driver after one baboon screamed when the driver passed by them. The angry baboons threw stones at the car and broke its windshield.

The study of animal emotions is an important endeavor, because not only will it allow us to achieve an understanding and appreciation of the lives of many of the animal beings with whom we share this splendid planet, it also will help us come to terms with how we "mind them"-especially how we treat our 
animal kin. One reason that many animals can form tight and reciprocal social bonds with one another and with humans is because of shared emotions. Emotions are the glue for the development and maintenance of these bonds.

Charles Darwin and Animal Emotions. Researchers interested in exploring animal passions ask such questions as: Do animals experience emotions? What, if anything, do they feel? Can we draw a line that clearly separates those species that experience emotions from those that do not? Much current research follows Charles Darwin's lead set forth in his book The Expression of the Emotions in Man and Animals ([1872] 1998). As I mentioned above, here and elsewhere Darwin argued that there is continuity, not large gaps, between humans and other animals in their emotional lives. The differences among many animals are differences in degree rather than differences in kind. In The Descent of Man and Selection in Relation to Sex Darwin claimed that "the lower animals, like man, manifestly feel pleasure and pain, happiness, and misery" ([1871] 1936, 448).

Naturalizing the Study of Animal Emotions: Facts and Feeling. Field research on animal emotions is of primary importance, for emotions have evolved in specific contexts. Naturalizing the study of animal emotions will provide for data more reliable than information collected in unnatural circumstances (although animals raised in extremely impoverished social environments display the deepest of grief ), because emotions have evolved just as have other behavioral patterns and organs, including stomachs, hearts, kidneys, and brains. Categorically denying emotions to animals because we cannot study them directly does not constitute a strong or reasonable argument against their existence. The same concerns could be mounted against evolutionary explanations of a wide variety of behavior patterns, stories that rely on facts that are impossible to verify precisely. In this sense, evolution is as private as the minds of other individuals. Thus, we can only make better or worse guesses about why a particular behavior pattern evolved.

Emotion and Cognition: How Are Emotions Experienced by Individuals? Perhaps the most difficult of unanswered questions concerning animal emotions deals with how emotions and cognition are linkedhow emotions are felt, or reflected on, by humans and other animals. We also do not know which species have the capacities to engage in conscious reflection about emotions and which do not. A combination of evolutionary, comparative, and developmental approaches set forth by Niko Tinbergen ([1951] 1989; 1963) and Gordon Burghardt (1991), combined with comparative studies of the neurobiological and endocrinological bases of emotions in various animals, including humans, carries much promise for future work concerned with relationships between cognition and individuals' experiences of various emotions.

In his book The Feeling of What Happens: Body and Emotion in the Making of Consciousness, Antonio Damasio (1999a; see also Damasio 1999b) provides a biological explanation for how emotions might be felt in humans. His explanation might also apply to some animals. Damasio suggests that various brain structures map both the organism and external objects to create what he calls a second-order representation. The mapping of the organism and the object most likely occurs in the thalamus and cingulate cortices. A sense of self in the act of knowing is created, and the individual knows "to whom this is happening." The "seer" and the "seen," the "thinker" and the "thought," are one and the same.

Clearly, an understanding of behavior and neurobiology is necessary if we are ever to understand how emotions and cognition are linked. It is essential that we learn as much as we can about individuals' private experiences, feelings, and mental states. If and how animals' emotions are experienced is a challenge for future research. 


\section{THE EVOLUTION OF EMOTIONS}

Darwin is usually credited with being the first scientist to give serious attention to the study of animal emotions. In his books On the Origin of Species (1859), The Descent of Man ([1871] 1936), and The Expression of the Emotions in Man and Animals ([1872] 1998), Darwin argued that there is continuity between humans and other animals in their emotional (and cognitive) lives-that there are transitional stages among species, not large gaps. The differences among many animals are differences in degree rather than differences in kind.

Darwin applied the comparative method to the study of emotional expression, using six methods: observations of infants; observations of the insane who, when compared to normal adults, were less able to hide their emotions; judgments of facial expressions created by electrical stimulation of facial muscles; analyses of paintings and sculptures; cross-cultural comparisons of expressions and gestures, especially of people distant from Europeans; and observations of animal expressions, especially those of domestic dogs.

Concerning continuity, I quote from one of the deans of ornithology, Alexander Skutch, who at 97 years of age is still conducting field research on birds in Costa Rica. In his delightful book The Minds of Birds, Skutch wrote:

It is remarkable how often the sounds that birds make suggest the emotions that we might feel in similar circumstances: soft notes like lullabies while calmly warming their eggs or nestlings; mournful cries while helplessly watching an intruder at their nests; harsh or grating sounds while threatening or attacking an enemy. . . Birds so frequently respond to events in tones such as we might use that we suspect their emotions are similar to our own. (Skutch 1996, 41-42)

A broad evolutionary and comparative approach to the study of emotions will help us learn more about the taxonomic distribution of emotions. For example, Michel Cabanac $(1999 ; 2000)$ has discovered that reptiles, such as iguanas, maximize sensory pleasure. He found that iguanas prefer to stay warm rather than venture out into the cold to get food, whereas amphibians such as frogs did not show such behavior. Neither did fish. Iguanas experience what is called "emotional fever" (a rise in body temperature) and tachycardia (increased heart rate), physiological responses that are associated with pleasure in other vertebrates, including humans. Cabanac postulated that the first mental event to emerge into consciousness was the ability of an individual to experience the sensations of pleasure or displeasure. Cabanac's research suggests that reptiles experience basic emotional states and that the ability to have an emotional life emerged between amphibians and early reptiles. His findings are consistent with some of Paul Maclean's theory of the triune brain.

Joy, Happiness, and Play. As I mentioned, social play is an excellent example of a behavior in which many animals engage, and one that they seem to enjoy immensely. Individuals become immersed in the activity, and there seems to be no goal other than to play. There is a feeling of incredible freedom in the flow of play.

Animals seek out play relentlessly, and when a potential partner does not respond to a play invitation they often turn to another individual. Specific play signals are used to initiate and to maintain play. If all potential partners refuse its invitation, an individual will play with objects or chase its own tail. The play mood is contagious; just seeing animals playing can stimulate play in others. Animals seek out play because it is fun. Consider my field notes of two dogs playing. 
Jethro runs towards Zeke, stops immediately in front of him, crouches or bows on his forelimbs, wags his tail, barks, and immediately lunges at him, bites his scruff and shakes his head rapidly from side to side, works his way around to his backside and mounts him, jumps off, does a rapid bow, lunges at his side and slams him with his hips, leaps up and bites his neck, and runs away. Zeke takes wild pursuit of Jethro and leaps on his back and bites his muzzle and then his scruff, and shakes his head rapidly from side to side. They then wrestle with one another and part, only for a few minutes. Jethro walks slowly over to Zeke, extends his paw toward Zeke's head, and nips at his ears. Zeke gets up and jumps on Jethro's back, bites him, and grasps him around his waist. They then fall to the ground and wrestle with their mouths. Then they chase one another and roll over and play.

It seems more difficult to deny that the animals were having fun and enjoying themselves than to accept that they enjoyed what they were doing.

Grief.

Never shall I forget watching as, three days after Flo's death, Flint climbed slowly into a tall tree near the stream. He walked along one of the branches, then stopped and stood motionless, staring down at an empty nest. After about two minutes he turned away and, with the movements of an old man, climbed down, walked a few steps, then lay, wide eyes staring ahead. The nest was one which he and Flo had shared a short while before Flo died. . . . In the presence of his big brother [Figan], [Flint] had seemed to shake off a little of his depression. But then he suddenly left the group and raced back to the place where Flo had died and there sank into ever deeper depression. . . . Flint became increasingly lethargic, refused food and, with his immune system thus weakened, fell sick. The last time I saw him alive, he was hollow-eyed, gaunt and utterly depressed, huddled in the vegetation close to where Flo had died. . . . The last short journey he made, pausing to rest every few feet, was to the very place where Flo's body had lain. There he stayed for several hours, sometimes staring and staring into the water. He struggled on a little further, then curled up—and never moved again. (Goodall 1990, 19697)

Many animals display grief at the loss or absence of another. One vivid description is offered above. Jane Goodall observed Flint, an eight-and-a-half year-old chimpanzee, withdraw from his group, stop feeding, and finally die after his mother, Flo, died. The Nobel laureate Konrad Lorenz observed grief in geese that was similar to grief in young children. He provided the following account: "A greylag goose that has lost its partner shows all the symptoms that John Bowlby has described in young human children in his famous book Infant Grief . . . the eyes sink deep into their sockets, and the individual has an overall drooping experience, literally letting the head hang ...." (Lorenz 1991, 251).

Other examples of grief are offered in my book The Smile of a Dolphin (2000b). Sea lion mothers, watching their babies being eaten by killer whales, squeal eerily and wail pitifully in anguish of their loss. Dolphins have been observed struggling to save a dead infant. Elephants have stood guard over a stillborn baby for days with their head and ears hung down, quiet and moving slowly. Orphan elephants who saw their mothers being killed often wake up screaming. Joyce Pool claims that grief and depression in orphan elephants is a real phenomenon. It has also been noted of traumatized orphaned gorillas: "The light in their eyes simply goes out, and they die" (McRae 2000, 86). Comparative research in neurobiology, endocrinology, and behavior is needed to learn more about the subjective nature of animal grief. 
Romantic Love. Courtship and mating are two activities in which numerous animals regularly engage. Many animals seem to fall in love with one another just as do humans. Recall that Heinrich is of the opinion that even ravens fall in love. In many species, romantic love slowly develops between potential mates. It is as if one or both needs to prove their worth to the other before they consummate their relationship.

Bernd Würsig (2000) has described courtship in southern right whales off Peninsula Valdis, Argentina. While courting, Aphro (female) and Butch (male) continuously touched flippers, began a slow caressing motion with them, rolled toward each other, briefly locked both sets of flippers as in a hug, and then rolled back up, lying side by side. They then swam off, side by side, touching, surfacing, and diving in unison. Würsig followed Butch and Aphro for about an hour, during which they continued their tight travel. Würsig believes that Aphro and Butch became powerfully attracted to each other and had at least a feeling of "afterglow" as they swam off. He asks, Could this not be leviathan love?

Many things have passed for love in humans, yet we do not deny its existence, nor are we hesitant to say that humans are capable of falling in love. It is unlikely that romantic love (or any emotion) first appeared in humans with no evolutionary precursors in animals. Indeed, there are common brain systems and homologous chemicals underlying love (and other emotions) that are shared among humans and animals. The presence of these neural pathways suggests that if humans can feel romantic love, then at least some other animals also experience this emotion.

Embarrassment. Some animals even seem to feel embarrassment. Goodall (2000) observed what could be called embarrassment in chimpanzees. When Fifi's oldest child, Freud, was five and a half years old, his uncle, Fifi's brother Figan, was the alpha male of the chimpanzee community. Freud always followed

Figan; he hero-worshipped the big male. Once, as Fifi groomed Figan, Freud climbed up the thin stem of a wild plantain. When he reached the leafy crown, he began swaying wildly back and forth. Had he been a human child, we would have said he was showing off. Suddenly the stem broke and Freud tumbled into the long grass. He was not hurt. He landed close to Goodall, and as his head emerged from the grass, she saw him look over at Figan-Had he noticed? If he had, he paid no attention but went on grooming. Freud very quietly climbed another tree and began to feed.

Marc Hauser (2000) observed what could be labeled embarrassment in a male rhesus monkey. After copulating, the male strutted away and accidentally fell into a ditch. He stood up and quickly looked around. Sensing that no other monkeys saw him tumble, he marched off, back high, head and tail up, as if nothing had happened. Once again, comparative research in neurobiology, endocrinology, and behavior is needed to learn more about the subjective nature of embarrassment.

\section{STUDYING ANIMAL EMOTIONS: WHERE TO FROM HERE?}

The best way to learn about the emotional lives of animals is to conduct comparative and evolutionary ethological, neurobiological, and endocrinological research and to resist critics' claims that anthropomorphism has no place in these efforts. To claim that we cannot understand elephants, dolphins, or other animals unless "we are one of them" gets us nowhere. It is important to try to learn how animals live in their own worlds, to understand their own perspectives. Animals evolved in specific and unique situations, and it discounts their lives if we try to understand them only from our own perspective. Certainly, gaining this kind of knowledge is difficult, but it is not impossible. Perhaps so little headway has been made in the study of animal emotions because of a fear of being nonscientific. In response to my invitation to contribute an essay to my forthcoming book on animal emotions, one colleague wrote: "I'm not sure what I can produce, but it certainly won't be scientific. And I am just not sure what I can say. I have not studied animals in natural circumstances and, though interested in emotions, I've 'noticed' few. 
Let me think about this." On the other hand, many other scientists were very eager to contribute. They believed that we can be scientific and at the same time use other types of data to learn about animal emotions - that it is permissible for scientists to write about matters of the heart (although at least one prominent biologist has had trouble publishing such material; Heinrich 1999, 322).

The Necessity for Biocentric Anthropomorphism. ". . . we are obliged to acknowledge that all psychic interpretation of animal behavior must be on the analogy of human experience. . . . Whether we will or no, we must be anthropomorphic in the notions we form of what takes place in the mind of an animal" (Washburn 1909, 13).

Anthropomorphism is inevitable. Unfortunately, many researchers have ignored what is so very obvious: We are humans, and we have by necessity a human view of the world. The way we describe and explain the behavior of other animals is limited by the language we use to talk about things in general. By engaging in anthropomorphism-using human terms to explain animals' emotions or feelings-we are making other animals' worlds accessible to ourselves. But this is not to say that other animals are happy or sad in the same ways in which humans (or even other conspecifics) are happy or sad. Of course, I cannot be absolutely certain that Jethro, my companion dog, is happy, sad, angry, upset, or in love, but these words serve to explain what he might be feeling. However, merely referring acontextually to the firing of different neurons or to the activity of different muscles in the absence of behavioral information and context is insufficiently informative. Using anthropomorphic language does not have to discount the animals' point of view. Anthropomorphism allows other animals' behavior and emotions to be accessible to us. Thus, I maintain that we can be biocentrically anthropomorphic and do rigorous science.

To make the use of anthropomorphism and anecdote more acceptable to those who feel uncomfortable describing animals with such words as happy, sad, depressed, or jealous, or those who do not think that mere stories about animals truly provide much useful information, Burghardt (1991) suggested the notion of critical anthropomorphism, in which various sources of information are used to generate ideas that may be useful in future research. These sources include natural history; individuals' perceptions, intuitions, and feelings; careful descriptions of behavior; identifying with the animal; optimization models; and previous studies.

Burghardt and others feel comfortable expanding science carefully to gain a better understanding of other animals (Burghardt 1997). However, Burghardt and other scientists who openly support the usefulness of anthropomorphism are not alone. Some scientists feel very comfortable attributing human emotions to, for example, the companion animals with whom they share their homes. These researchers often tell stories of how happy their dog Fido is when they arrive at home, how sad Fido looks when they leave him at home or take away a chew bone, how Fido misses his buddies, or how smart Fido is for figuring out how to get around an obstacle. Yet, when the same scientists enter their laboratories, dogs and other animals become objects, and talking about their emotional lives or how intelligent they are is taboo.

One answer to the question of why dogs and other animals are viewed differently at "work" and at home is that at work, dogs are subjected to a wide variety of treatments that would be difficult to administer to one's companion. This is supported by recent research. Based on a series of interviews with practicing scientists, sociologist Mary Phillips $(1994,119)$ reported that many of them construct a "distinct category of animal, the 'laboratory animal,' that contrasts with namable animals (e.g., pets) across every salient dimension ... the cat or dog in the laboratory is perceived by researchers as ontologically different from the pet dog or cat at home."

Meet the Devil. Jaak Panksepp (1998) provides a useful thought experiment. Imagine that you are faced with making a devil's choice concerning the existence of animal emotions. You must answer correctly the 
question of whether or not other mammals have internally experienced emotional feelings. If you give the wrong answer you will follow the devil home. In other words, the stakes are high. Panksepp asks how many scientists would deny under these circumstances that at least some animals have feelings, and concludes: likely, very few.

There is much disagreement about the emotional lives of other animals, but we are learning more and more each day as researchers from different disciplines tackle the difficult questions that I have laid out above.

The following questions can be used to set the stage for learning more about the evolution and expression of animal emotions: Our moods move us, so why not other animals? Emotions help us to manage and regulate our relationships with others, so why not for other animals? Emotions are important for humans to adapt to specific circumstances, so why not for other animals? Emotions are an integral part of human life, so why not for other animals?

Current research suggests that no one single theory of emotions can explain all of the psychological phenomena that are called emotions. There is no doubt that there is continuity between the neurobehavioral systems that underlie human and nonhuman emotions, that the differences between human and animal emotions are, in many instances, differences in degree rather than differences in kind.

In remaining open to the idea that many animals have rich emotional lives, even if we are wrong in some cases, little truly is lost. If we close the door on the possibility that many animals have rich emotional lives, even if they are very different from our own or from those of animals with whom we are most familiar, we will lose great opportunities to learn about the lives of animals with whom we share this wondrous planet.

The future holds many challenges and perhaps surprises for those who want to learn more about animal emotions. The rigorous study of animal emotions will require harnessing the best possible resources. These resources include researchers in various scientific disciplines who provide hard data and anecdotes, other scholars who study animals, nonacademics who observe animals and tell stories, and the animals themselves. There is ample room for hard and soft science in the study of animal emotions.

There are many worlds beyond human experience. There are no substitutes for listening to and having direct experiences with other animals. We truly can ask such questions as, Do animals love one another? Do they mourn the loss of friends and loved ones? Do they resent others? Can they be embarrassed? Certainly our own lives will be richer for the effort and the lives of other animals more understood, appreciated, and respected.

\section{ANIMALS AS "PERSONS": MY MOTHER AND MY MUTT}

Before I conclude I want to mention a topic that increasingly has been pursued by philosophers, legal scholars, and a handful of biologists (see various essays in Cavalieri and Singer 1993 and Cavalieri 1998, and references therein; see also Regan 1983; Degrazia 1997; Francione 2000; Wise 2000). It is the topic of personhood (in philosophical and legal arenas, though the discussion crosses these disciplines) and whether or not nonhuman animals can be considered to be persons. Discussing the status of animals as possible persons forces us to consider what makes us human. The study of animal cognition and emotions is central to questions about personhood.

A brief story about my mother lays out the basic questions that need to be considered.

Once, when I was visiting my parents, my deeply caring, passionate, and devoted father asked, "Marc, can you please wheel Mom into the kitchen and get her ready for dinner?" I answered, "Sure, Dad," and 
began the short trek. But the journey went well beyond the confines of my parents' home. It remains a difficult and multidimensional pilgrimage for which there are not any road maps or dress rehearsals. I watch myself watching Mom. The role reversal is riveting; I am now my keeper's keeper. Where (and who) is the person I called "Mom"?

My mother, Beatrice Rose, whom I love dearly, has suffered major losses of locomotor, cognitive, and physiological functions. She does not know who I am, and likely she has lost some self- and body awareness. In a nutshell, my mother has lost her autonomy. She has little self-determination. Nevertheless, there is no doubt others would still think of her as a "person" whose spirit and soul reside within and who is entitled to certain moral and legal standing. And in my view they should.

Generally, the following criteria are used to designate a being as a person. They include: being conscious of one's surroundings, being able to reason, experiencing various emotions, having a sense of self, adjusting to changing situations, and performing various cognitive and intellectual tasks. While many humans fulfill most if not all of these criteria, there are humans who do not -young infants and seriously mentally challenged adults. But they are also rightfully considered to be persons.

Now, what about my companion dog, Jethro? He is active, can feed and groom himself, and is very emotional. Jethro is as autonomous as a dog can be. Yet, many people would not feel comfortable calling Jethro a person.

Why the different attitudes toward my mother and Jethro? Why are some people, especially in Western cultures, hesitant to call chimpanzees, gorillas, dolphins, elephants, wolves, and dogs "persons," even when they meet the criteria for personhood, more so than some humans? I believe it is because of fear. People fear that elevating animal beings to persons would mean that the notion of personhood is tarnished, that it means less for humans. Some also fear that animals will then have the same legal and moral standing as humans and they will be equals.

While some may believe this whole exercise is crass, there are very important issues at stake. Loving Jethro (and other animals) as much as I do does not mean I love my mother (or other humans) less. Does granting Jethro and other animals personhood and attendant moral and legal standing lessen or take moral and legal standing away from humans? No. Such fears are not warranted.

Little is to be gained by claiming that granting personhood to some animals would be a misguided or blasphemous move. Surely, Jethro goes through life differently from most human (and other dog) beings, but this does not mean he has no life at all. People vary greatly-there are countless different personalities-but the term person is broad enough to encompass (and celebrate) this marvelous diversity.

Calling a nonhuman a person does not degrade the notion of personhood. However, this move would mean that animals would come to be treated with respect, compassion, and love, that their interests in not suffering would be given equal consideration with those of humans. Could one reasonably argue that a world with less cruelty and more compassion and love would not be a better place to live and raise children? I do not think so.

\section{DOG TRUST AND DEATH: DEEP LESSONS IN SPIRITUALITY}

It is in our relations with our companion animals (pets) that our humanness comes to the fore. Dogs and other companion animals (hereafter companions) are amazing beings. Our companions with whom we share our lives typically have unqualified trust in us-they believe we will always have their best interests in mind, they love us unconditionally when they choose to love us, and they would do almost anything for 
us. And, indeed, often they do, taking care of us and causing themselves harm in selflessly doing so. Dogs and other companions also engage us with the natural world and, indeed, with ourselves. They force us to look deeply inside of ourselves if we choose to allow ourselves to make this often difficult journey, and to come to terms with just who we are in the grand scheme of things. Our companions offer important lessons in spirituality and can be catalysts in our weaving a seamless tapestry with all life in which the interconnections are rich, deep, and innumerable.

Sacred and Boundless Trust. Trust is central to the formation and maintenance of close bonds among animals. What does it mean to say our companions trust us? The notion of trust is difficult to define, because it is very broad and slippery. Trust is closely related to intention-what a person or other being intends to do, and whether their actions are in the best interest of another being. It is possible to have the best of intentions and to do something that harms another being. This does not mean that the person or other animal who erred should not ever be trusted again.

What about the trust that our companion animals have in us? Their wide eyes seem to tell us that they just know we will always do the best we can for them. I find it easiest to think about dog trust in terms of what dogs expect from us, their innate, evolved or ancestral, and deep faith in us, their unwavering belief that we will take our responsibilities to them as seriously as we assume responsibility for other humans. Basically, our companions expect that we always will have their best interests in mind, that we will care for them and be concerned with maximizing their well-being. So, we regularly feed and exercise our companions, we scratch them behind their ears that vary in size and shape, we rub their bellies and watch them succumb to our touch, melting like hot butter as our fingers massage them into deep relaxation. We also hug them, love them, welcome them into our homes as family members (which pleases them immensely because they are such social beings), and we take them to a veterinarian when they need medical care. They feel better because of our devotion to them, and, indeed, we also feel better as we lovingly care for them. We are their trusted guardians, not their "owners." We do not own our companions as we own such property as our bicycles and backpacks, and surely we must not treat them like disposable objects or "things."

Causing Pain with Compassion. Having said this, on occasion we may also intentionally expose our companions to painful situations, such as allowing them to receive vaccinations or to undergo surgery, when we believe that it is in their best interests. We have not betrayed their trust by causing them intentional pain. Jethro needed acupuncture for bad arthritis in his left elbow, and he clearly did not like it the first two times he was stuck with the needles. But afterwards he settled in and went through the treatments with no hesitancy, even dragging me into the veterinarian's office! His eyes told me that he trusted me and our wonderful veterinarian to take care of him, and as I watched the needles have their beneficial effects I tapped into my own spirituality and my love for Jethro, feelings that were inextricably linked to his deep trust of us.

The pain to which Jethro was exposed was caused intentionally by me and the veterinarian. But we did not betray his trust in us. However, if we beat our companions or otherwise abuse them, leave them in a hot car, starve them, neglect their need for love, or allow them to be abused in horrible experiments, we have betrayed them. In most instances they will still trust us in the future. It's just who they are-who they have become via the evolutionary process of domestication. Dogs are so attached to humans that many people have seen dogs being abused in experiments and in other situations, only to look up at the abuser and wag their tails as if to say, "This hurts me, but you must mean well-how could you possibly mean otherwise?" Their dog-talk says it all. Charles Darwin reportedly left medical school because he was "repulsed" by dog experiments. He wrote of a man who experimented on dogs: "unless he had a heart of stone, [he] must have felt remorse to the last hour of his life" (Darwin [1871] 1936, 449). I also left a 
graduate medical program because I did not want to kill cats or dogs as part of my education "in the name of science." I did not want to kill animals to learn about life and gave up a lifelong dream.

Dead Dog Walking. Our responsibilities to our companions lead us into difficult waters when we choose to end their pains and suffering, to "euthanize" them or "put them to sleep." It is when we make the decision to be responsible for the last breath of another individual that our "humanness" and spirituality are clearly shown. Let me tell you a story that brings these ideas to the fore.

For thirteen years I shared my home with Inuk, a huge white malamute. Over and over he would say to me, "Come on, Marc, it's time for a hike, or dinner, or a belly rub." I was constantly on call for him. As Inuk got older it became clear that our lives together would soon be over. The uninhibited and exuberant wagging of his huge tail that cooled me in the summer, occasionally knocked glasses off the table, and told me how happy he was would soon stop. What should I do-let him live in misery or help him die peacefully with dignity? It was my call.

Because our companions are so dependent on us, we are responsible for making difficult decisions about when to end their lives, to "put them to sleep." I have been faced with this situation many times and have anguished trying to do what is right for my buddies. Should I let them live a bit longer, or has the time really come to say good-bye? When Inuk got old and could hardly walk, eat, or hold down food, the time had come to put him out of his misery. I stopped feeding him the medicine that made him sick so he could live a few extra weeks. Instead, I fed him ice cream and cookies, and he began to thrive. But this was only a brief respite; Inuk was dying right in front of my eyes, and I knew it. Even when eating ice cream he seemed miserable.

Deciding when to end an animal's life is a real-life moral drama. There are not any dress rehearsals, and doing it once does not make doing it again any easier. Inuk knew I would do what was best for him, and I really came to feel that often he would look at me and say, "It's okay, please take me out of my misery and lessen your burden. Let me have a dignified ending to what was a great life. Neither of us feels better letting me go on like this."

Finally, I chose to let Inuk leave this earth in peace. After countless hugs and "I love you's" I recall that Inuk boldly strode into the veterinarian's office, knowing as a content "dead dog walking" what was happening, and he accepted his fate with valor, grace, and honor. I feel he also told me that the moral dilemma with which I was faced was no predicament at all, that I had indeed done all I could and that his trust in me and love for me were not compromised, but rather, perhaps, strengthened. I had made the right choice, as difficult as it was, and Inuk openly thanked me for it. He was a dog of few barks but clearly let me know how he felt in this situation.

Killing as Healing. I killed Inuk. No matter how one puts it, I choose to kill him with compassionate euthanasia. But Inuk's trust and love for me also helped me heal the deep psychological wounds that I suffered when I decided to help him die so as to end his suffering. In the process I faced directly the deep grief that penetrated every one of my cells, indeed permeated my entire being. The tears that poured out of my eyes and streamed down my face at the time contained the spirit and soul of Inuk, and indeed the spirits and souls of all of the other companions whose lives I chose to end in the most humane and compassionate way I knew. These companions gave me the opportunity to come to terms with my own humanness. The rituals of putting Inuk and other companions out of their misery-recognizing that their lives were nearing an end, thanking them for their companionship, trust, devotion, and love, telling them how much I valued and loved them, and coming to terms with the awesome responsibilities that I took on by sharing my life with them-were deep lessons in spirituality and love. 


\section{GIVING THANKS TO KINDRED SPIRITS}

Our animal companions are spiritual and soulful beings abounding in generosity and love. We can learn much from them about compassion, devotion, respect, spirituality, and love. By honoring a dog's trust we can tap into our own spirituality and humanness. Unfortunately, this journey entails not only filling their lives with love but mercifully taking their lives when their own spirit has died and their life's spark is gone.

Dogs and other animals tell us that they trust and love us by their actions-their willingness to allow us to do just about anything to them. It is important to remember this when we interact with them. It is a malicious double-cross to betray their inviolable trust in our having their best interests in mind. Remember that in most cases our companions will joyfully prance back for more of what we dish out, always expecting that we really do have their best interests in mind. They are that trusting and confident.

The pioneering and courageous holistic veterinarian, Allen Schoen, has recently written a wonderful and inspirational book titled Kindred Spirits: How the Remarkable Bond between Humans and Animals Can Change the Way We Live (2001). Schoen suggests that we "go forth and make a conscious, active effort to rejoice in the interconnectedness of all of life, every day. Love yourself by extending love to all other living beings ... do something special to support the beauty of life on our one and only planet, Mother Earth" (p. 200). This is good, heartfelt advice, coming from a traditionally trained veterinarian who has gone beyond the narrow confines of scientific autonomy, authority, and presumed objectivity.

Creating a Soulscape. We severely harm our companions psychologically and physically when we let them down, neglect them, or dominate them, selfishly ignoring the deep hurt for which we are responsible. When we betray our companions' innocence and trust, our actions are ethically indefensible and we become less than human.

Our companions' hearts, like our own, are very fragile, and we must be very gentle with them. Their and our heartbeats are synchronous; we nourish one another's spirit and soul. We can never be too generous with our love for our dear and trusting companions, who are so full of forgiveness and grace and are deeply pure of heart. Indeed, by honoring our companions' trust in us and love for us we can view our own spirituality in a mirror in which all life is clearly reflected and boundlessly interconnected.

Our companions can make us more human and humane if we open ourselves to the depths of their presence and the essence of their being. So, what can we do?

Here are a few suggestions: Let us make every effort to understand and to appreciate the essence of our companions. Let us praise them openly and thank them for who they are as we embrace their lessons in compassion, devotion, respect, spirituality, and love. Their lives and ours will be richer, more fulfilled, complete, and radiant. Love will abound, and the awe-inspiring universe as a whole will become a better place-a soulscape - in which to live in harmony with all of our kin, other life, and inanimate landscapes. Surely, a more compassionate world will be a better place in which to raise our children and theirs with grace and humility.

The Importance of Ethological Studies. "I study foxes because I am still awed by their extraordinary beauty, because they outwit me, because they keep the wind and the rain on my face . . because it is fun" (Macdonald 1987, 15).

In my view, we need much more than traditional science-science that is not socially responsible, science that is autonomous and authoritarian, science that fragments the universe and disembodies and alienates humans and other animals - to make headway into understanding other animals and the world at large. We need to broaden science to incorporate feeling, heart, spirit, soul, and love. Scientists need to exit 
their heads and go to their hearts, and science needs to open its arms to people who love the world and who have a reverence for all life. We need a science of unity; a science of reconciliation.

How we view ourselves and other animals informs how we interact with and treat our animal kin. There are many lessons to be learned. Open discussions about science, spirituality, religion, love, and God will enable us better to come to terms with who we are in this splendid, awe-inspiring universe. Ethological studies motivated by compassion, respect, understanding, appreciation, and love are needed. Some lines from a poem by Thich Nhat Hanh with which Schoen (2001) ends his book are important to consider: "We are the shared emotions of all our brethren, We are truly a kindred spirit with all of life" (p. 257). I feel blessed when I open myself to the heart, spirit, and soul of other animals (see also Randour, 2000). I feel that I am a better scientist by being open rather than (ideologically, in the dogma of science) closing the door on such rich and deep experiences. When I study coyotes I am coyote; when I study birds I am bird. Often when I stare at a tree, I am tree. There is a strong sense of oneness. We are all part of the same deeply interconnected and interdependent community in which I, the seer, am the seen, woven into a seamless tapestry of unity with interconnecting and reciprocal bonds.

\section{WHERE TO FROM HERE? LOVING EARTH}

My own spirituality is based on a deep drive for a seamless unity that is motivated by compassion, respect, and love. During my brief tenure on this wondrous planet, I am more than happy to open the door of my heart to all beings. I dream of and envision a unified, peaceable kingdom-a peaceful kinshipbased on respect, compassion, forgiveness, and love.

I am a hard-core optimist, victimized by hope. I ache with the pains of other beings and also feel pangs when I see inanimate landscapes being destroyed. I prefer to imagine that we all live in a soulscape bounded by, and immersed in, mutual compassion, respect, grace, and love. This is how I maintain unflagging hope. I remain hopeful that we can make this a better world because we are a very special species-not better than other species-and that interdisciplinary discussions at many different levels of organization of who we are will make for better science, better theology, and a close and enduring marriage of the two. Indeed, we are rather petite in the large universe in which we live, petite but powerful, and we need to proceed with humility. We need to tread lightly, watching every step that we take.

It is essential to maintain hope even when things seem grim. Rather than take a doomsday view that the world won't exist in a hundred years if we fail to accept our unique responsibilities, it is even more disturbing to imagine a world in which humans and other life coexist in the absence of any intimacy and interconnectedness. Surely we do not want to be remembered as the generation that killed nature. Now is the time for everyone to work for peace with other humans, other animals, and with all of nature-for universal, planetary peace.

We can love animals more without loving people less. We need to be motivated by love and not by fear of what it will mean if we come to love animals for who they are. They need to be understood in their own worlds.

As we learn about other animals and how important they are to us, we will learn more about ourselves. This knowledge and the intense feelings they bring forth will help make us better to one another and to the planet as whole. We need to do this now and be proactive, for we have limited time. Time is not on our side mainly because we are so powerful and ubiquitous. Cooperation among representatives from different disciplines combined with holism and pluralism will surely help us learn that science and religion are not incompatible. The study of animal behavior can help us immensely. 
If we forget that humans and other animals are all part of the same interdependent world-the more-thanhuman world (Abram 1996) - and if we forget that humans and animals are deeply connected at many levels, when things go amiss in our interactions with animals (as they surely will), and animals are set apart from and inevitably "below" humans, I feel certain that we will miss the animals more than the animal survivors will miss us. The interconnectivity and spirit of the world will be lost, and these losses will make for a severely impoverished universe.

In the end, it boils down to love. The power of love must not be underestimated as we try to reconnect with nature and other animals (Ehrenfeld 1981; Goodall 1999; Pollock 1999; Sewall 1999; Bekoff 2000a; Goodall and Bekoff in press). We must love the Earth and the universe and all of their inhabitants, animate and inanimate.

In the grand scheme of things, individuals receive what they give. If love is poured out in abundance, it will be returned in abundance, and there is no fear of exhausting the potent self-reinforcing feeling that serves as a powerful stimulant for generating compassion, respect, and more love for all life. It is important to recognize that each individual plays an essential role and that each individual's spirit and love are intertwined with the spirit and love of others. These emergent interrelationships, which transcend individuals' embodied selves, foster a sense of oneness and can work in harmony to make this a better and more compassionate world for all beings.

So, as I have argued before and will continue to argue, when animals and other wild nature lose, we all lose. We must "stroll with our kin" and not leave them in our tumultuous wake of rampant destruction (Bekoff 2000d). Holism and universal compassion and love need to replace impersonal, objective reductionism that alienates and disembodies individuals and dispenses with or fragments their hearts, their spirits, and their souls.

It is essential that we do better than our ancestors, and we surely have the resources to do so. The big question is whether we will choose to make the proactive commitment to making this a better world-a more compassionate world in which love is plentiful and shared-before it is too late.

\section{NOTES}

Special thanks to Sharon Adams for talking through much of this material with me. Much of my discussion of the evolution of social morality appeared in Bekoff 2001, and some of my discussion of animal emotions appeared in Bekoff 2000c.

${ }^{1}$ At a meeting in Chicago, Illinois, in August 2000 dealing with social organization and social complexity, it was hinted to me that while my ideas about social morality are interesting, there really is no way that social carnivores could be said to be so decent-to behave (play) fairly-because it was unlikely that even nonhuman primates were this virtuous.

\section{REFERENCES}

Abram, D. 1996. The Spell of the Sensuous: Perception and Language in a More-Than-Human World. New York: Pantheon.

Aldis, Owen. 1975. Play Fighting. New York: Academic Press.

Allen, C., and M. Bekoff. 1997. Species of Mind: The Philosophy and Biology of Cognitive Ethology. Cambridge: M.I.T. Press.

Aureli, F., and F. B. M. de Waal. 2000. Natural Conflict Resolution. Berkeley: Univ. of California Press.

Aviles, L. 1999. "Cooperation and Non-linear Dynamics: An Ecological Perspective on the Evolution of Sociality." Evolutionary Ecology Research 1:459-77. 
Axelrod, R. 1984. The Evolution of Cooperation. New York: Basic Books.

Bekoff, Marc. 1975. "The Communication of Play Intention: Are Play Signals Functional?" Semiotica 15:231-39.

- 1977a. "Social Communication in Canids: Evidence for the Evolution of a Stereotyped Mammalian Display." Science 197:1097-99.

_ 1977b. "Mammalian Dispersal and the Ontogeny of Individual Behavioral Phenotypes." American Naturalist 111:715-32.

_ 1995. "Play Signals as Punctuation: The Structure of Social Play in Canids." Behaviour 132:419_ 29.

_ 1998a. "Minding Animals." In Responsible Conduct of Research in Animal Behavior, ed. L. Hart, 96-116. New York: Oxford Univ. Press.

—. 1998b. "Deep Ethology, Animal Rights, and the Great Ape/Animal Project: Resisting Speciesism and Expanding the Community of Equals." Journal of Agricultural and Environmental Ethics 10:269-96.

—, ed. 1998c. Encyclopedia of Animal Rights and Animal Welfare. Westport, Conn.: Greenwood Publishers.

- 2000a. "Redecorating Nature: Reflections on Science, Holism, Humility, Community, Reconciliation, Spirit, Compassion, and Love." Human Ecology Review 7:59-67.

- ed. 2000b. The Smile of a Dolphin: Remarkable Accounts of Animal Emotions. New York: Random House, Discovery Books.

_. 2000c. "Animal Emotions: Exploring Passionate Natures." BioScience 50:861-70.

—. 2000d. Strolling with our Kin: Speaking for and Respecting Voiceless Animals. New York: Lantern Books.

- 2001. "Social Play Behaviour, Cooperation, Fairness, Trust and the Evolution of Morality." Journal of Consciousness Studies 8:81-90.

_. In press. Minding Animals: Science, Nature, and Heart. New York: Oxford Univ. Press.

Bekoff, Marc, and C. Allen. 1992. "Intentional Icons: Towards an Evolutionary Cognitive Ethology." Ethology 91:1-16.

- 1998. "Intentional Communication and Social Play: How and Why Animals Negotiate and Agree to Play. In Animal Play: Evolutionary, Comparative, and Ecological Perspectives, ed. M. Bekoff and J. A. Byers, 97-114. New York: Cambridge Univ. Press.

Bekoff, M., C. Allen, and G. M. Burghardt, eds. In press. The Cognitive Animals. Cambridge: M.I.T. Press.

Bekoff, M., and J. A. Byers. 1981. "A Critical Reanalysis of the Ontogeny of Mammalian Social and Locomotor Play: An Ethological Hornet's Nest." In Behavioral Development: The Bielefeld Interdisciplinary Project, ed. K. Immelmann, G. W. Barlow, L. Petrinovich, and M. Main, 296-337. New York: Cambridge Univ. Press.

Bekoff, M., and J. A. Byers, eds. 1998. Animal Play: Evolutionary, Comparative, and Ecological Perspectives. New York: Cambridge Univ. Press.

Bekoff, M., and D. Jamieson. 1996. "Ethics and the Study of Carnivores." In Carnivore Behavior, Ecology, and Evolution, ed. J. L. Gittleman, 16-45. Ithaca, N.Y.: Cornell Univ. Press.

Bernstein, Irwin S. 2000. "The Law of Parsimony Prevails: Missing Premises Allow Any Conclusion." Journal of Consciousness Studies 7:31-34.

Boehm, C. 1999. Hierarchy in the Forest: The Evolution of Egalitarian Behavior. Cambridge: Harvard Univ. Press.

Bradley, B. J. 1999. "Levels of Selection, Altruism, and Primate Behavior." Quarterly Review of Biology 74:171-94.

Burghardt, Gordon M. 1991. "Cognitive Ethology and Critical Anthropomorphism: A Snake with Two Heads and Hognose Snakes that Play Dead." In Cognitive Ethology: The Minds of Other 
Animals-Essays in Honor of Donald R. Griffin, ed. C. A. Ristau, 53-90. Hillsdale, N.J.: Lawrence Earlbaum Associates.

- 1997. "Amending Tinbergen: A Fifth Aim for Ethology." In Anthropomorphism, Anecdote, and Animals: The Emperor's New Clothes? ed. R. W. Mitchell, N. Thompson, and L. Miles, 254-76. Albany: SUNY Press.

In press. The Genesis of Play. Cambridge: M.I.T. Press.

Cabanac, Michel. 1999. "Emotion and Phylogeny." Journal of Consciousness Studies 6:176-90.

2000. "Emotional Fever." In The Smile of a Dolphin: Remarkable Accounts of Animal Emotions, ed. M. Bekoff, 194-97. New York: Random House, Discovery Books.

Cavalieri, P., ed. 1998. Special issue devoted to nonhuman personhood. Etica \& Animali.

Cavalieri, P., and P. Singer, eds. 1993. The Great Ape Project. London: Fourth Estate.

Comstock, W. P. 1947. "Peculiar Behavior of a Red Fox." Journal of Mammalogy 28:405.

cummings, e e. 1953. Six Non-lectures. Cambridge, Mass.: Harvard Univ. Press.

Dalai Lama. 1999. The Path to Tranquility: Daily Wisdom. New York: Viking Arkana.

Damasio, Antonio. 1999a. The Feeling of What Happens: Body and Emotion in the Making of Consciousness. New York: Harcourt Brace.

1999b. "How the Brain Creates the Mind." Scientific American 281:112-17.

Darwin, Charles. 1859. On the Origin of Species By Means of Natural Selection. London: Murray.

_ . [1871] 1936. The Descent of Man and Selection in Relation to Sex. New York: Random House.

- [1872] 1998. The Expression of the Emotions in Man and Animals. 3d ed. Introduction, Afterword, and Commentaries by Paul Ekman. New York: Oxford Univ. Press.

Degrazia, D. 1997. "Great Apes, Dolphins, and the Concept of Personhood." The Southern Journal of Philosophy 35:301.

Dugatkin, L. A. 1997. Cooperation Among Animals: An Evolutionary Perspective. New York: Oxford Univ. Press.

Dugatkin, L. A., and M. Bekoff. Forthcoming. "The Evolution of Fairness: A Game-Theoretic Model."

Ehrenfeld, D. 1981. The Arrogance of Humanism. New York: Oxford Univ. Press.

Fagen, Robert. 1981. Animal Play Behavior. New York: Oxford Univ. Press.

- 1993. "Primate Juveniles and Primate Play." In Juvenile Primates: Life History, Development, and Behavior, ed. M. E. Pereira and L. A. Fairbanks, 183-96. New York: Oxford Univ. Press.

Flack, J. C., and Frans de Waal. 2000. "Any Animal Whatever: Darwinian Building Blocks of Morality in Monkeys and Apes." Journal of Consciousness Studies 7:1-29.

Forster, D. In press. "Distributed Cognition in Olive Baboons: A Systems Approach to Mind." In The Cognitive Animals, ed. M. Bekoff, C. Allen, and G. M. Burghardt. Cambridge: M.I.T. Press.

Francione, G. 2000. Introduction to Animal Rights: Your Child or the Dog. Philadelphia: Temple Univ. Press.

Frith, Chris, and Uta Frith. 1999. "Interacting Minds-A Biological Basis." Science 286: 1692-95.

Gallese, Vittorio. 1998. "Mirror Neurons, from Grasping to Language." Consciousness Bulletin (Fall), 3-4.

Gallese, Vittorio, and Alvin Goldman. 1998. "Mirror Neurons and the Simulation Theory of Mind-Reading." Trends in Cognitive Science 2:493-501.

Gibbons, M. 1999. "Science's New Social Contract with Society." Nature 402:C81-C84.

Goodall, Jane. 1990. Through a Window. Boston: Houghton Mifflin. . 1999. Reason for Hope: A Spiritual Journey. New York: Warner Books.

2000. "Pride Goeth Before a Fall." In The Smile of a Dolphin: Remarkable Accounts of Animal Emotions, ed. M. Bekoff, 166-67. New York: Random House, Discovery Books.

Goodall, Jane, and Marc Bekoff. In press. Ten Covenants. San Francisco: HarperCollins.

Gould, S. J., and E. A. Lloyd. 1999. "Individuality and Adaptation across Levels of Selection: How Shall We Name and Generalize the Unit of Darwinism?" Proceedings of the National Academy of Sciences 96:11904-09. 
Gruen, Lori. In press. "The Morals of Animal Minds." In The Cognitive Animals, ed. M. Bekoff, C. Allen, and G. M. Burghardt. Cambridge: M.I.T. Press.

Güzeldere, G., and E. Nahmias. In press. "Darwin's Continuum and the Building Blocks of Deception." In The Cognitive Animals, ed. M. Bekoff, C. Allen, and G. M. Burghardt. Cambridge: M.I.T. Press.

Hauser, Marc. 2000. "A Lover's Embarrassment?" In The Smile of a Dolphin: Remarkable Accounts of Animal Emotions, ed. M. Bekoff, 200-201. New York: Random House, Discovery Books.

Heinrich, Bernd. 1999. Mind of the Raven: Investigations and Adventures with Wolf-Birds. New York: Cliff Street Books.

Hill, H. L., and M. Bekoff. 1977. "The Variability of Some Motor Components of Social Play and Agonistic Behaviour in Eastern Coyotes, Canis latrans var." Animal Behaviour 25:907-9.

Hill, Julia Butterfly. 2000. The Legacy of Luna. San Francisco: HarperCollins.

Kitchen, D. M., and C. Packer. 1999. "Complexity in Vertebrate Societies." In Levels of Selection in Evolution, ed. L. Keller, 176-96. Princeton, N.J.: Princeton Univ. Press.

Leigh, E. G. Jr. 1999. "Levels of Selection, Potential Conflicts, and Their Resolution: Role of the 'Common Good."' In Levels of Selection in Evolution, ed. L. Keller, 15-30. Princeton, N.J.: Princeton Univ. Press.

Lorenz, K. Z. 1991. Here I Am—Where Are You? New York: Harcourt Brace Jovanovich.

Lorimer, D. 1999. "Introduction: From Experiment to Experience." In The Spirit of Science: From Experiment to Experience, ed. D. Lorimer, 17-29. New York: Continuum.

Macdonald, David. 1987. Running with the Fox. New York: Facts on File.

Mackey, B. G. 1999. "Environmental Scientists, Advocacy, and the Future of Earth." Environmental Conservation 26:245-49.

Marler, Peter. 1996. "Social Cognition: Are Primates Smarter than Birds?" In Current Ornithology, vol. 13, ed. V. Nolan Jr. and E. D. Ketterson, 1-32. New York: Plenum Press.

Mayr, E. 2000. "Darwin's Influence on Modern Thought." Scientific American 283:67-71.

McRae, M. 2000. "Central Africa's Orphaned Gorillas: Will They Survive the Wild?" National Geographic 197:84-97.

Mech, David. 1970. The Wolf. Garden City, N.Y.: Doubleday.

Moser, Anton. 2000. "The Wisdom of Nature in Integrating Science, Ethics and the Arts." Science and Engineering Ethics 6:365-82.

Motluk, A. 2001. "Read My Mind." New Scientist 169:22-26.

Panksepp, Jaak. 1998. Affective Neuroscience. New York: Oxford Univ. Press.

- 2000. "The Rat Will Play." In The Smile of a Dolphin: Remarkable Accounts of Animal Emotions, ed. M. Bekoff, 146-47. New York: Random House, Discovery Books.

Pellis, S. In press. "Keeping in Touch: Play Fighting and Social Knowledge." In The Cognitive Animals, ed. M. Bekoff, C. Allen, and G. M. Burghardt. Cambridge: M.I.T. Press.

Peterson, Gregory R. 1999. "The Evolution of Consciousness and the Theology of Nature." Zygon: Journal of Religion and Science 34 (June): 283-306.

—. 2000. "God, Genes, and Cognizing Agents." Zygon: Journal of Religion and Science 35 (September): 469-80.

Phillips Mary T. 1994. "Proper Names and the Social Construction of Biography: The Negative Case of Laboratory Animals." Qualitative Sociology 17:119-42.

Pollock, R. 1999. The Missing Moment: How the Unconscious Shapes Modern Science. Boston: Houghton Mifflin.

Poole, Joyce. 1998. "An Exploration of a Commonality between Ourselves and Elephants." Etica \& Animali 9:85-110.

Power, T. G. 2000. Play and Exploration in Children and Animals. Hillsdale, N.J.: Lawrence Erlbaum Associates. 
Randour, M. L. 2000. Animal Grace: Entering Spiritual Relationship with Our Fellow Creatures. Novato, Calif.: New World Library.

Regan, T. 1983. The Case for Animal Rights. Berkeley: Univ. of California Press.

Ridley, Mark. 1996. The Origins of Virtue: Human Instincts and the Evolution of Cooperation. New York: Viking.

Rolston, Holmes III. 1999. Genesis, Genes, and God: Values and Their Origins in Natural and Human History. New York: Cambridge Univ. Press.

Schaller, G. B., and G. R. Lowther. 1969. "The Relevance of Carnivore Behavior to the Study of Early Hominids." Southwestern Journal of Anthropology 25:307-41.

Schoen, A. 2001. Kindred Spirits: How the Remarkable Bond between Humans and Animals Can Change the Way We Live. New York: Broadway Books.

Scott, J. P., and J. L. Fuller. 1965. Genetics and the Social Behavior of the Dog. Chicago: Univ. of Chicago Press.

Sewall, L. 1999. Sight and Sensibility: The Ecopsychology of Perception. New York: Jeremy P. Tarcher/Putnan.

Singer, P. 1999. A Darwinian Left: Politics, Evolution, and Cooperation. New Haven: Yale Univ. Press.

Skutch, A. 1996. The Minds of Birds. College Station: Texas A \& M Univ. Press.

Skyrms, B. 1996. Evolution of the Social Contract. New York: Cambridge Univ. Press.

Siviy, S. 1998. "Neurobiological Substrates of Play Behavior: Glimpses into the Structure and Function of Mammalian Playfulness." In Animal Play: Evolutionary, Comparative, and Ecological Perspectives, ed. M. Bekoff and J. A. Byers, 221-42. New York: Cambridge Univ. Press.

Smith, Huston. 2001. Why Religion Matters. San Francisco: Harper.

Sober, Elliott, and D. S. Wilson. 1998. Unto Others: The Evolution and Psychology of Unselfish Behavior. Cambridge: Harvard Univ. Press.

- 2000. "Summary of: Unto Others: The Evolution and Psychology of Unselfish Behavior." Journal of Consciousness Studies 7:185-206.

Spinka, M., R. C. Newberry, and M. Bekoff. 2001. "Mammalian Play: Training for the Unexpected." Quarterly Review of Biology 76:141-68.

Thompson, P. R. 1975. "A Cross-Species Analysis of Carnivore, Primate, and Hominid Behavior." Journal of Human Evolution 4:113-24.

Tinbergen, Niko. [1951] 1989. The Study of Instinct. New York: Oxford Univ. Press.

—. 1963. "On Aims and Methods of Ethology." Zeitschrift für Tierpsychologie 20: 410-33.

- 1972. Introduction to Hans Kruuk, The Spotted Hyena. Chicago: Univ. of Chicago Press.

Tomasello, Michael, and Josep Call. 1997. Primate Cognition. New York: Oxford Univ. Press.

Washburn, Margaret F. 1909. The Animal Mind: A Text-book of Comparative Psychology. London: Macmillan.

Watson, Duncan M., and David B. Croft. 1996. "Age-Related Differences in Playfighting Strategies of Captive Male Red-Necked Wallabies (Macropus rufogriseus banksianus)." Ethology 102:336-46.

Wise, S. M. 2000. Rattling the Cage: Towards Legal Rights for Animals. Cambridge, Mass.: Perseus Books.

Würsig, Bernd. 2000. "Leviathan Lust and Love." In The Smile of a Dolphin: Remarkable Accounts of Animal Emotions, ed. M. Bekoff, 62-65. New York: Random House, Discovery Books. 